\title{
KOMUNIKASI EFEKTIF DALAM DUNIA PENDIDIKAN
}

\author{
Yossita Wisman \\ Universitas Palangka Raya Kalimantan Tengah \\ yossitayosie@yahoo.com
}

\begin{abstract}
Learning process (learning) is a change that is relatively fixed in behaving. so, the learning process puts one person from one ability or ability status to another skill / ability. The process of communication in the delivery of a goal is more than simply channeling thoughts or ideas and intentions orally or in writing. The communication method consists of: (1) informative communiation, a message delivered to a person / a number of people about the new things he / she knows. (2) persuasive communication (persuasive communication) is the process of influencing one's attitude, outlook, or behavior in the form of persuasive and inviting activities, so that he performs with his own consciousness. (3) instructive / coercive communication, are: communications that contain threats / penance in the nature of coercion, so that the targeted people do something forced, for fear of the consequences.
\end{abstract}

Keywords : learning,ability,attention,interest,communication

\begin{abstract}
Abstrak
Proses belajar (learning) adalah suatu perubahan yang relative tetap dalam bertingkah laku. jadi, proses belajar menempatkan seseorang dari status kemampuan atau kecakapan (Ability) yang satu kepada kemampuan/kecakapan yang lain. Proses Komunikasi dalam penyampaian suatu tujuan lebih dari pada sekedar menyalurkan pikiran-pikiran atau gagasan-gagasan dan maksud-maksud secara lisan atau tertulis. Metode komunikasi terdiri dari atas : (1) komunikasi informative (informative communiation), suatu pesan yang disampaikan kepada seseorang/sejumlah orang tentang hal-hal baru yang diketahuinya. (2) komunikasi persuasive (persuasive communication), adalah proses mempengaruhi sikap, pandangan,atau perilaku seseorang dalam bentuk kegiatan membujuk dan mengajak, sehingga ia melakukan dengan kesadaran sendiri. (3) komunikasi instruktif/koersif (instructive/coercive communication), adalah : komunikasi yang mengandung ancaman/sangsi dalam yang besifat paksaan, sehingga orang-orang yang dijadikan sasaran melakukan sesuatu secara terpaksa, karena takut akibatnya.
\end{abstract}

Kata Kunci : Proses belajar, kecakapan, Perhatian, Ketertarikan, Komunikasi 


\section{PENDAHULUAN}

Sebagai makhluk sosial, manusia tak bisa lepas dari komunikasi. Entah komunikasi verbal maupun non verbal. Dalam segala bidang, tak terkecuali pendidikan, komunikasi menjadi salah satu hal yang sangat penting. Dalam proses pembelajaran, komunikasi digunakan untuk menyampaikan pesan, baik itu berupa ilmu pengetahuan maupun teknologi. Berhasil tidaknya informasi yang disampaikan kepada para peserta didik sangat ditentukan oleh keefektifan komunikasi. Untuk menciptakan proses komunikasi yang efektif, pendidik harus memahami seluk beluk komunikasi pendidikan, antara lain mengenai metode yang tepat dalam komunikasi pendidikan, strategi untuk meningkatkan efektivitas komunikasi dalam pendidikan, serta yang tak kalah pentingnya adalah mengenai hambatan yang seringkali muncul dalam komunikasi pendidikan.

$$
\text { Hasil penelitian Miftah (2012) }
$$

metode komunikasi yang dipakai dalam dunia pendidikan menentukan tingkat efektifitas komunikasi. Agar jalannya komunikasi berkualitas, maka diperlukan suatu pendekatan komunikasi yaitu; pendekatan secara ontologis (definisi komunikasi), tetapi juga secara aksiologis (proses berlangsungnya komunikasi yang efektif) dan secara epistemologis (kegunaan komunikasi itu dilaksanakan). Hal penting yang perlu diperhatikan saat proses informasi untuk komunikasi dalam pembelajaran, antara lain: (1) isi sebagai outcome, (2) tingkat intelegensi dan pengalaman siswa, (3) keaktifan siswa dalam proses belajar, (4) kemajuan dan umpan balik dari siswa, dan (5) kesempatan siswa untuk berlatih.

Tidak cukup hanya mengetahui dan memahami hal-hal tersebut, pendidik juga harus mampu menerapkan metode komunikasi yang tepat dalam kegiatan pembelajaran dan strategi yang tepat untuk meningkatkan efektivitas komunikasi dalam pendidikan. Selain itu, pendidik juga harus mampu mengantisipasi dan mengatasi hambatan komunikasi, baik yang berasal dari peserta didik maupun pendidik itu sendiri. Maka dari itu, hal-hal tersebut penting sekali untuk dibahas dan dikaji.

Penelitian ini memiliki tujuan
menggali metode yang tepat dalam
komunikasi pendidikan, strategi untuk
meningkatkan efektivitas komunikasi dalam
pendidikan. Selain itu, juga memahami
tentang hambatan dalan komunikasi
pendidikan. Hal ini disebabkan penelitian ini
membahas tentang metode komunikasi,
strategi untuk meningkatkan efektifitas
komunikasi serta hambatan dalam
komunikasi pendidikan. Makalah ini hanya
membahas tentang metode yang tepat dalam
komunikasi pendidikan, strategi untuk
meningkatkan efektivitaas komunikasi
dalam pendidikan, serta hambatan dalam
komunikasi pendidikan.

\section{TINJAUAN PUSTAKA}

\section{Komunikasi Pendidikan}

Metode komunikasi digunakan agar komunikasi antar manusia terjalin secara efektif. Pengertian metode adalah suatu cara yang digunakan untuk melakukan sesuatu hal. Metode komunikasi sering kali dikenal dengan teknik komunikasi, yaitu cara yang 
digunakan dalam menyampaikan informasi dari komunikator ke komunikan dengan media tertentu. Dengan adanya teknik ini diharapkan setiap orang dapat secara efektif melakukan komunikasi satu sama lain dan secara tepat menggunakannya (Mulyana, 2005).

Effendy (2006) metode komunikasi terdiri atas :

1. Komunikasi informative (informative communication), suatu pesan yang disampaikan kepada seseorang atau sejumlah orang tentang hal-hal baru yang diketahuinya.

2. Komunikasi persuasif (persuasive communication), proses mempengaruhi sikap, pandangan, atau perilaku seseorang dalam bentuk kegiatan membujuk dan mengajak, sehingga ia melakukan dengan kesadaran sendiri.

3. Komunikasi

instruktif/koersif (instructive/coercive communication), komunikasi yang mengandung ancaman, sangsi, dan lain-lain yang bersifat paksaan, sehingga orang-orang yang dijadikan sasaran melakukan sesuatu secara terpaksa, karena takut akibatnya.

Pengalaman bersama merupakan suatu yang amat penting dalam proses komunikasi, karena ketidaksamaan pengalaman dapat mengakibatkan kesulitan berkomunikasi. Ada beberapa faktor yang menyebabkan perbedaan pengalaman antara satu dengan lainnya; antara lain sebagai berikut: Faktor usia, jenis kelamin, ekonomi, lokasi, pendidikan, organisasi, serta pekerjaan (Mulyo, 2001 : 5)

Setyosari (2006: 1) menyatakan bahwa pembelajaran berbasis masalah adalah suatu metode atau cara pembelajaran yang ditandai oleh adanya masalah nyata, sebagai konteks bagi peserta didik untuk belajar kritis dan ketrampilan memecahkan masalah dan memperoleh pengetahuan.

Berikut diberikan lima contoh model pembelajaran yang memiliki kecenderungan berlandaskan paradigma konstruktivistik, yaitu: model reasoning and problem solving, model inquiry training, model problembased instruction, model pembelajaran perubahan konseptual, dan model group investigation.(Santyasa, 2007)

\section{Strategi Komunikasi Efektif}

Menurut Effendy (2008) komunikasi dikatakan tidak efektif apabila seperti beberapaindikator berikut:

1. Perbedaan Persepsi

2. Reaksi emosional

3. Ketidak-konsistenan komunikasi verbal dan nonverbal

4. Kecurigaan

5. Tidak adanya timbal balik (feedback) Komunikasi efektif berkaitan dengan kemampuan (ability) komunikator dan komunikannya. Kemampuan adalah kesanggupan, kecakapan, kekuatan kitaberusaha dengan diri sendiri (Moeliono, 2005: 707). Menurut Soelaiman (2007:112) kemampuan adalah sifat yang dibawa lahir atau dipelajari yangmemungkinkan seseorang yang dapat menyelesaikan pekerjaannya, baiksecara mental ataupun fisik.

Aspek-aspek yang paling penting dalam kemampuan komunikasi secara efektif terdiri dari komunikator, komunikan, media yaitu alat untuk menyampaikan danpesan sesuatu 
yang disampaikan. Karena selain dari tiga aspek tersebut semuanya sudah mengacu kepada kurikulum yang berlaku (kompetensi inti dan kompetensi dasar) baik yang berupa pesan/materi pelajaranataupun efek komunikasi yang biasanya berupa nilai prestasi belajar (Handayani, 2011).

Strategi komunikasi mempunyai fungsi yang berkaitan dengan kegiatan:1. Menyebarluaskan pesan komunikasi kepada sasaran untuk memperoleh hasilyang optimal.2. Menjembatani kesenjangan budaya akibat kemudahan yang diperoleh dankemudahan dioperasionalkannya media massa. (Achmad, dkk, 2013:33)

\section{Hambatan Komunikasi Pendidikan}

Menurut Ron Ludlow \& Fergus Panton (1992 : 10-11), hambatan-hambatan yang menyebabkan komunikasi tidak efektif yaitu :

\section{Status effect}

Adanya perbedaaan pengaruh status sosial yang dimiliki setiap manusia.

\section{Semantic Problems}

Faktor semantik menyangkut bahasa yang dipergunakan komunikator sebagai alat untuk menyalurkan pikiran dan perasaannya kepada komunikan.

\section{Perceptual distorsion}

Cara pandang yang sempit pada diri sendiri dan perbedaaan cara berpikir serta cara mengerti yang sempit terhadap orang lain.

\section{Cultural Differences}

Perbedaan kebudayaan, agama, dan lingkungan sosial.

\section{Physical Distractions}

Gangguan lingkungan fisik terhadap proses berlangsungnya komunikasi.

\section{Poor choice of communication channels} Media yang dipergunakan dalam melancarkan komunikasi.

\section{No Feed back}

Tidak ada respon dan tanggapan dari receiver .

Pentingnya sebuah komunikasi yang akurat dan baik sehingga apabila kesusksesan komunikasi tidak dapat diwujudkan maka akan mampu menimbulkan hambatan bagi komunikator dan komunikannya (Fallatehan, 2011).

\section{HASIL PENELITIAN DAN PEMBAHASAN}

\section{Metode yang Tepat dalam Komunikasi Pendidikan}

Dalam penyampaian materi pembelajaran kepada peserta didik, ada beberapa faktor yang perlu dipertimbangkan, diantaranya adalah peserta didik, ruangan kelas, metode, dan materi itu sendiri. Untuk dapat mencapai tujuan yang telah ditetapkan pada suatu kegiatan pembelajaran, metode pembelajaran dan komunikasi harus mendapat perhatian khusus dalam setiap proses pembelajaran. Metode pembelajaran dan komunikasi tidak selalu harus sama untuk setiap materi.

Proses belajar (learning) adalah suatu perubahan yang relatif tetap dalam bertingkah laku, yang terjadi sebagai hasil pengalaman. Ini berarti, hanya dapat dikatakan terjadi proses belajar bila seseorang menunjukkan tingkah laku yang tidak sama. Jadi, proses belajar menempatkan seseorang dari status kemampuan atau kecakapan (ability) yang 
satu kepada kemampuan/kecakapan yang lain.

Pengajar yang baik seharusnya memahami karakteristik siswanya agar ia sukses dalam melaksanakan peran mengajarnya. Dalam proses belajar mengajar, kemungkinan akan menemui siswa yang sulit untuk melakukan kontak dengan dunia sekitarnya, suka mengasingkan diri, dan cenderung menutup diri. Dalam kaitan dengan hal ini, maka dosen/guru hendaknya merencanakan proses belajar mengajar yang sesuai dengan keadaan dan kepribadian mahasiswa.

Proses komunikasi dalam menyampaikan suatu tujuan lebih daripada sekedar menyalurkan pikiran-pikiran atau gagasan-gagasan dan maksud-maksud secara lisan atau tertulis. Komunikasi secara lisan pada umumnya lebih mendatangkan hasil dan pengertian yang lebih jelas daripada secara tertulis. Garis-garis komunikasi hendaknya dibuat sependek dan selangsung mungkin.

\section{Strategi untuk Meningkatkan Efektifitas dalam Komunikasi Pendidikan}

Strategi komunikasi yang merupakan paduan perencanaan komunikasi dengan menajemen komunikasi untuk mencapai tujuan yang telah ditetapkan. Strategi komunikasi ini harus mampu menunjukkan bagaimana operasional praktis yang harus dilakukan, dalam arti bahwa pendekatan bisa berbeda-beda sewaktu-waktu tergantung pada situasi dan kondisi.

\section{Mengenali sasaran komunikasi}

Sebelum melakukan komunikasi, kita perlu mempelajari person yang akan menjadi sasaran komunikasi tersebut. Hal tersebut bergantung pada tujuan komunikasi.

2. Pemilihan media komunikasi

Media komunikasi sangat banyak jumlahnya, mulai dari yang tradisional sampai dengan modern. Untuk mencapai sasaran komunikasi, kita bisa memilih salah satu atau menggabungkan beberapa media, tergantung pada tujuan yang akan dicapai, pesan yang akan disampaikan, dan teknik yang akan dipergunakan.

3. Pengkajian tujuan pesan komunikasi

Pesan komunikasi memiliki tujuan tertentu. Ini menentukan teknik yang akan diambil.

4. Peranan komunikator dalam komunikasi yakni ada pada daya tarik dan kredibikitas.

Berdasarkan kedua faktor tersebut seorang komunikator dalam menghadapi komunikan, haruslah bersikap empatik, yaitu kemampuan seseorang untuk memproyeksikan dirinya kepada peranan orang lain. Dengan kata lain, dapat merasakan apa yang dirasakan orang lain. Seorang komunikator harus bersikap empatik ketika ia berkomunikasi dengan komunikan yang sedang sibuk, marah, bingung, sedih, sakit, kecewa, dan sebagainya.

Komunikasi yang efektif dalam pembelajaran banyak ditentukan oleh keaktifan pebelajar dan pembelajar dalam bentuk timbal balik berupa pertanyaan, jawaban pertanyaan atau berupa perbuatan baik secara fisik maupun secara mental. Adanya umpan balik ini memungkinkan pembelajar mengadakan perbaikanperbaikan cara komunikasi yang pernah dilakukan. Keefektifan komunikasi 


\section{JURNAL NOMOSLECA}

Volume 3, Nomor 2, Oktober 2017

menunjuk kepada kemampuan orang untuk menciptakan suatu pesan dengan tepat, yaitu pengirim pesan dapat mengetahui bahwa penerima menginterprestasikan sama dengan apa yang dimaksudkan oleh si pengirim.

Selain itu keefektifan pembelajaran sangat ditentukan oleh adanya perhatian dan minat pebelajar. Ini sesuai dengan model "AIDA singkatan dari perhatian (Attention), minat (Interest), hasrat (Desire), dan kegiatan (Action)". Maksudnya agar terjadi kegiatan pada diri pebelajar sebagai komunikan, maka terlebih dahulu harus dibangkitkan perhatian dan minatnya kemudian dilanjutkan dengan penyajian bahan. Komunikasi yang jelas dalam sebuah pembelajaran adalah salah satu syarat pembelajaran dapat berlangsung efektif. Jadi bila kita ingin menjadi guru yang efektif, marilah kita bersama-sama memperbaiki kemampuan kita berkomunikasi kepada siswa-siswa kita pada setiap pembelajaran yang kita laksanakan.

Dalam komunikasi yang efektif, terdapat lima hal yang perlu diperhatikan:

1. Respect, jika kita harus mengkritik atau memarahi seseorang, lakukan dengan penuh respek terhadap harga diri dan kebanggaan seseorang. Sebuah penghargaan yang tulus kepada siswa, membuat siswa dapat membedakan antara perlakuan yang tulus dan tidak tulus. Berikan penghargaan maka Anda sebagai seorang pendidik akan dihargai oleh siswa. Berikan penghargaan maka proses belajar mengajar menjadi sebuah proses yang menyenangkan bagi semua pihak.

2. Emphaty, perlu saling memahami dan mengerti keberadaan, perilaku, dan keinginan dari siswa. Jadi sebelum kita membangun komunikasi atau mengirimkan pesan, kita perlu mengerti dan memahami dengan empati calon penerima pesan kita. Sehingga nantinya pesan kita akan dapat tersampaikan tanpa ada halangan psikologi atau penolakan dari penerima.

3. Audible, dapat didengarkan atau dimengerti dengan baik, berarti pesan yang kita sampaikan bisa diterima dengan baik oleh penerima pesan.

4. Clarity, perlu mengembangkan sikap terbuka (tidak ada yang ditutupi atau disembunyikan), sehingga dapat menimbulkan rasa percaya (trust) dari penerima pesan. Karena tanpa keterbukaan akan timbul sikap saling curiga dan pada gilirannya akan menurunkan semangat dan antusiasme siswa dalam proses belajar-mengajar.

5. Humble, dengan menghargai orang lain, mau mendengar, menerima kritik, tidak sombong, dan tidak memandang rendah orang lain

\section{Hambatan dalam Komunikasi Pendidikan}

Hambatan komunikasi bisa dimaknai dengan ganguan (noise) dalam proses komunikasi. Hambatan dalam komunikasi pendidikan memiliki pengaruh yang sangat besar terhadap efektifitasnya proses belajar mengajar. Terdapat hambatan semantik dan hambatan saluran.

1. Gangguan saluran (channel noise). Berkaitan dengan kendala atau hambatan yang berhubungan dengan fisik penyampaian pesan. Terjadi antara 
komunikator dan komunikan yang menggunakan saluran berupa media.

2. Gangguan semantik. Sedangkan ganguan semantik merupakan ganguan yang berhubungan demgan tata kebahasaan dimana ganguan ini sering terjadi karena kesenjangan atau ketidaksesuaian antara pesan yang disampakan komunikator kepada komunikannya.

Sumber gangguan semantik sebagai berikut:

a. Kata-kata terlalu sukar , masalahnya terlalu sukar dimengerti oleh penerima.

b. Perbedaan dalam memberikan arti denotatif pada kata-kata yang digunakan antara pengirim dan penerima pesan, yakni penerima pesan berpikir bahwa kata yang dimaksud menunjukkan pada sesuatu yang berbeda dengan yang dimaksud oleh pengirimnya.

c. Pola kalimat yang membingungkan penerima pesan.

d. Perbedaan budaya antara pengirim dan penerima pesan, yakni intonasi, gerak mata, tangan, atau bagian badan lainnya.

Fajar mengklasifikasikan hambatan komunikasi terutama dalam dunia pendidikan antara lain sebagai berikut:

1. Hambatan dari proses komunikasi

a. Hambatan dari pengirim pesan, misalnya pesan yang akan disampaikan belum jelas bagi dirinya atau pengirim pesan. Hal ini dipengaruhi oleh perasaan atau situasi emosional, sehingga mempengaruhi motivasi yaitu mendorong seseorang untuk bertindak sesuai dengan keinginan, kebutuhan, atau kepentingan. b. Hambatan dalam penyandian atau symbol, hal ini dapat terjadi karena bahasa yang dipergunakan tidak jelas sehingga memiliki arti lebih dari satu, symbol yang dipergunakan antara si pengirim dengan penerima tidak sama atau bahasa yang dipergunakan terlalu sulit.

c. Hambatan media, adalah hambatan yang terjadi dalam penggunaan media komunikasi.

d. Hambatan dari penerima pesan, misalnya kurangnya perhatian pada saat menerima atau mendengarkan pesan, atau tidak mencari informasi lebih lanjut.

e. Hambatan dalam memberikan balikan. Balikan yang diberikan tidak menggambarkan apa adanya, akan tetapi interpretatif, tidak tepat waktu, atau tidak jelas, dan sebagainya.

2. Hambatan fisik Hambatan fisik dapat mengganggu komunikasi yang efektif, misalnya:

a. Gangguan kesehatan

b. Gangguan pada alat-alat komunikasi dan jaringan listrik

3. Hambatan semantik

Kata-kata yang digunakan dalam komunikasi kadang-kadang mempunyai arti mendua yag berbeda, tidak jelas, atau berbelit-belit antara pemberi pesan dengan penerima pesan.

4. Hambatan psikologis

Hambatan psikologis dan sosial kadang-kadang mengganggu komunikasi.

Dalam musibah, misalkan, menimbulkan trauma yang sangat tinggi pada korbannya, sehingga pada 
saat diajak komunikasi menjadi tidak nyambung. Selain itu juga karena masalah prasangka, yang merupakan penilaian sejak awal dalam diri komunikan terhadap komunikator. Biasanya prasangka ini terlalu besar dan negatif, sehingga menjadi hambatan berat dalam komunikasi.

\section{PENUTUP}

\section{Simpulan}

1. Metode yang tepat dalam komunikasi pendidikan adalah dengan komunikasi secara langsung maupun tak langsung, disesuaikan dengan situasi dan kondisi.

2. Strategi untuk meningkatkan efektivitas komunikasi dalam pendidikan adalah dengan mengenali sasaran komunikasi, memilih media komunikasi yang tepat, mengkaji tujuan pesan komunikasi, dan memaksimalkan peranan komunikator dalam komunikasi.

3. Hambatan dalam komunikasi pendidikan, antara lain:
a. Hambatan dalam proses komunikasi
b. Hambatan fisik
c. Hambatan semantik
d. Hambatan psikologis

\section{Saran}

1. Dalam pendidikan, komunikasi memegang peranan penting. Oleh sebab itu, pendidik harus memahami metode, strategi, dan hambatan komunikasi dalam pendidikan, sehingga komunikasi dalam proses pembelajaran bisa berlangsung secara efektif.

2. Semoga makalah ini bermanfaat bagi penulis pada khususnya, dan bagi pembaca pada umumnya.

\section{DAFTAR PUSTAKA}

Achmad, dkk. 2013. Panduan Lengkap Jamur. Jakarta: Penebar Swadaya.

Effendy, Onong Uchjana. 2006. Ilmu Komunikasi Teori dan Praktek. Bandung : PT Remaja Rosdakarya. Mulyana, Deddy. 2005. Ilmu Komunikasi: Suatu Pengantar. Bandung : PT Remaja Rosda Karya.

Effendy, Onong Uchjana. 2008. Dinamika

Komunikasi. Bandung: Remaja Rosdakarya.

Fajar, Marhaeni. 2009. Ilmu Komunikasi Teori \& Praktek Edisi Pertama. Yogyakarta : Graha Ilmu.

Falletehan, Dama Paundra. 2011. Hambatan

Komunikasi Dalam Film "Yours Truly”.

https://jurnal.usu.ac.id/index.php/flow/ article/viewFile/12799/5556 Diakses 12 September 2017.

Handayani, Tutut. 2011. Membangun Komunikasi Efektif Untuk Meningkatkan Kualitas Dalam Proses Belajar Mengajar. TA'DIB, Vol. XVI, No. 02, Edisi Nopember 2011. http://download.portalgaruda.org/arti cle.php?Diakses 4 September 2017.

Ludlow, Ron \& Fergus Panton. 1992. The Essence of Effective Communication. London : Prentice Hall.

Miftah, M. 2012. Komunikasi Efektif Dalam Pembelajaran. 
http://web.unair.ac.id/admin/file/f_359

69_komunikasi-2012.pdf. Diakses 22 September 2017.

Moeliono, Anton M. 2003. Kamus Besar

Bahasa Indonesia. Jakarta : Depdikbud.

Mulyo, Prabowo. 2001. Sistem Komunikasi Pendidikan. Yogyakarta : Universitas Negeri Yogyakarya Press.

Santyasa, I Wayan. 2007. Model-Model Pembelajaran Inovatif. https://s3.amazonaws.com/academia.e du.documents/41170972/MODEL_MO DEL_PEMBELAJARAN.pdf?AWSAcce ssKeyId $=$ AKIAIWOWYYGZ2Y53UL3A $\&$ Expires $=1518423546 \&$ Signature $=O$ b6ehk8pmp4UkpdObK842nb\%2FJIO\% $3 D \&$ response-contentdisposition=inline\%3B\%20filename \%3DMODEL_MODEL_PEMBELAJA RAN.pdf. Diakses 5 September 2017.

Setyosari, Punaji. 2006. Belajar berbasis masalah (Problem based learning). Makalah disampaikan dalam Pelatihan Dosen-dosen PGSD FIP UNY di Malang pada Juli 2006.

Soelaiman. 2007. Manajemen Kinerja ; Langkah Efektif untuk Membangun,Mengendalikan dan Evaluasi Kerja, . Jakarta: PT. Intermedia Personalia Utama. 